\title{
ESL Learning Experiences of Immigrant Students in High Schools in a Small City
}

Lucy Karanja

Immigrant students who attend high schools in small Canadian cities are likely to be few in each school. Consequently, they may receive limited English as a second language (ESL) services and support by school personnel. This study aimed to acquire a deeper understanding of the organization and provision of ESL services in high schools in a small city with few immigrant students. Results indicate that the limited ESL support and services available in these schools pose challenges to the educational success of these students; however, sufficient resources and support would enable meeting their educational needs better, even given their low numbers. Suggestions for improvements are provided.

Les immigrants qui étudient dans des écoles secondaires des petites villes canadiennes courent le risque de se retrouver seulement quelques-uns par école. En conséquence, il se peut que les services et l'appui en ALS offerts par l'école soient limités. L'objectif de cette étude était de mieux comprendre l'organisation et l'offre de services en ALS dans les écoles secondaires d'une petite ville avec quelques élèves immigrants. Selon nos résultats, le fait que les services et l'appui offerts en ALS soient limités enfreint la réussite pédagogique des élèves; par contre, des ressources et un appui adéquats permettraient de mieux répondre aux besoins de ces élèves, même si le nombre de ceux-ci est limité. Nous proposons quelques idées visant l'amélioration de cette situation.

\section{Introduction}

Immigration patterns in recent years have resulted in demographic changes in English-speaking countries such as Canada, Australia, the United States, and the United Kingdom (Ashworth, 2000; Coelho, 1994a; Parkin \& Sidnell, 1992). These patterns have brought learners with diverse cultural and linguistic backgrounds into the school systems of these countries. The challenge for school jurisdictions in these countries is to adjust their pedagogy, teacher education, and teaching resources in order to meet the educational needs of learners from varied cultural and linguistic backgrounds (SpangenbergUrbschat \& Pritchard, 1994).

Although many studies have investigated how schools in English-speaking countries respond to the educational needs of immigrant students, most research has focused on schools in large urban areas where immigrant students are concentrated (Derwing, DeCorby, Ichikawa, \& Jamieson, 1999; 
Gunderson, 2000; Hébert \& Reis, 1999; Watt \& Roessingh, 1994). Such studies have given little attention to how context shapes ESL policies and practices. For example, few researchers have explored the effect of having proportionately few ESL students in a school; yet having small numbers of ESL students may affect not only decisions to provide ESL programs in such schools, but also on policy decisions regarding funding, provision of qualified ESL teachers, and availability of teaching and learning materials.

This study investigated ESL learning experiences of immigrant students in high schools in a small city (hereafter referred to as Cliftwood) in British Columbia (BC), Canada. I aimed to acquire a deeper understanding of how ESL services were organized and provided in schools in a small city where immigrant students were few in each school, as opposed to schools in big cities where immigrant students may be many. The operational definition of few immigrant students in this study was the unavailability of a homogeneous group of at least 30 ESL students in each school. The total number of ESL students in both schools where this study was conducted was slightly fewer than 30 of approximately 2,300 students.

The following general questions guided this study: What is the nature of ESL programs in high schools in a small city? How do ESL students perceive ESL programs and their ESL learning experiences? How do ESL teachers, subject area teachers, and the parents of ESL students perceive ESL programs and the experiences of ESL students? What effect on ESL students' social and academic lives is caused by their experiences and the nature of the ESL services available to them?

\section{Theoretical Framework}

This study was grounded in sociocultural theories of second language acquisition (SLA), especially as influenced by Vygotsky's (1978) psycholinguistic theoretical insights. Vygotsky's sociocultural approach to language learning departs from the individualistic cognitive approaches of SLA theories based on such aspects as input-output processing and encoding and decoding, instead of on a socially mediated language-learning viewpoint. Vygotsky's sociocultural perspective on SLA stresses the interdependence of social and individual processes in the co-construction of knowledge: language, a socially constituted and historically developed psychological tool, mediates social interactions and higher mental processes, enabling humans to participate in their social and intellectual worlds.

Vygotsky's (1978) notion of the Zone of Proximal Development (ZPD) further grounds SLA in a sociocultural approach. In SLA, mastery of the target language and of course content depends on language learners' interactions with their peers as well as with their teachers. The teacher determines the students' current linguistic and course-content knowledge levels, presents tasks, and resources that are appropriate, and then mediates learn- 
ing to help students master information at a higher level (Adair-Hauck \& Donato, 1994). Appropriate and meaningful learning opportunities and relevant resources/activities available to second-language learners are important for successful learning in the ZPD (Toohey \& Norton, 2001).

In a sociocultural perspective on SLA, interaction is viewed as facilitating ESL students' co-construction of knowledge. This interaction becomes more critical in the case of ESL students who represent a small population in a school because they may lack members of their own communities with whom to interact at school. The limited ESL programs and resources that are likely to be found in schools with few ESL students will not only hamper interaction opportunities for ESL students as a group, but also reduce opportunities to meet individual students' linguistic and academic needs.

\section{ESL Practices and Services}

Most English-speaking countries with immigrant students have designed ESL programs aimed at addressing the linguistic needs of this group. These programs are varied and are delivered variously in other countries (Ashworth, 2000; Baker, 1996). No particular program model is suitable for all schools or students; programs may vary depending on the policy orientations of the state or province, the school size, the available resources, and the needs of individual students (Brinton, Sasser, \& Winningham, 1991; Coelho, 1998). Table 1 highlights three ESL program models commonly used in Canada.

Despite the array of ESL programs aimed at helping immigrant students learn English and use it to master curriculum content, studies of immigrant high school students' education reveal unsatisfactory services for these students, making high school graduation an unattainable goal for most (Derwing et al., 1999; Watt \& Roessingh, 1994, 2001; Watt, Roessingh, \& Bosetti, 1996). Services and support available to ESL students determine the quality of academic and social assistance that they receive. Unfortunately, the funding for ESL programs is typically unstable and insufficient, making it difficult to plan for long-term developments in ESL services (Ashworth, 2000; Leung, 2001). In addition, some school jurisdictions such as the BC Ministry of Education (2004) set a five-year limit on ESL funding for students in their schools. This is regrettable because funders and educational planners seem not to not recognize that non-English-speaking immigrant students may take between four and eight years to develop cognitive academic language proficiency for successful academic achievement (Cummins, 1981; Collier, 1987). Students who attend Canadian high schools soon after immigrating to Canada have five years or less in which to learn English and use it to study curriculum content: the time for learning English is critical, and therefore adequate ESL services are important. 
Table 1

Highlights of Three Commonly Used ESL Program Models in Canada

\begin{tabular}{ll}
\hline Program Model & Description \\
\hline Self-contained & $\begin{array}{l}\text { Designed for students with little or no English knowledge. Students } \\
\text { spend either full days for one year in an ESL class or half a day in an } \\
\text { ESL class and half in a regular classroom taking courses that are less } \\
\text { demanding of their English proficiency. } \\
\text { Withdrawal/Pullout }\end{array}$ \\
$\begin{array}{l}\text { Students are withdrawn in groups based on English-language or } \\
\text { grade levels. They are timetabled for ESL classes alongside regular } \\
\text { classes and are withdrawn for ESL instruction at an ESL class or } \\
\text { center. } \\
\text { Mainstreaming }\end{array}$ & $\begin{array}{l}\text { Students are integrated into a regular classroom either with in-class } \\
\text { help from an ESL teacher or without any ESL support. }\end{array}$ \\
\hline
\end{tabular}

Source. Compiled from Baker (1996) and Ashworth (2000).

Studies of the academic achievement of ESL students (Derwing et al., 1999; Watt \& Roessingh, 1994, 2001) have found a high dropout rate for that group compared with their mainstream peers. Reasons contributing to high dropout rates include mainstreaming ESL learners with little or no continued ESL support, imposition of a fixed length for ESL support regardless of individual needs, failure by school administrators to promote support for ESL programs and students, and enforcement of an age cap of 19 years for ESL students' attendance at high school, after which they are pushed out of the regular school system. Indeed, former ESL students in a study by Watt et al. (1996) expressed frustration at being rushed into mainstream classrooms too quickly; they realized that their level of English knowledge was not sufficient to succeed in an all-English setting without further ESL support. Some dropped out of school for fear of failure. In addition, ESL students in one culturally and linguistically diversified region of $\mathrm{BC}$ reported that other students and teachers held them and their ESL classes in low esteem, making them perceive themselves as second-class students (Gunderson, 2000). Studies of ESL students' education have reported the importance of teachers, counselors, and coaches taking an active role as supportive adults (Hébert \& Reis, 1999; Watt et al., 1996). However, such support is not always available to ESL students, which puts them at risk of dropping out of school (Ponsford \& Lapadat, 2001).

\section{Method}

\section{Design}

This study followed a case study design, using qualitative paradigm principles (Lincoln \& Guba, 1984), which provided a means of capturing the 
uniqueness of one ESL program and of students' experiences in Cliftwood high schools (Yin, 2003). In addition, the design permitted investigation of the participants in their natural settings (Merriam, 1988; Yin). This design provided a framework for situating second-language acquisition in the social context in which it took place (Miller, 1997).

\section{Participants}

I interviewed 10 participants in this study: three ESL students (Camille, Fiki, and Juan), two ESL teachers (Cindy and Jason), three parents of ESL students (Nadia, Edem, and Natalia), and two mainstream teachers (Kathy and Wayne). All names are pseudonyms. Student and teacher participants were from two high schools in Cliftwood. The students interviewed had been in Canada for the same number of years as they had been receiving ESL support in their schools. They were still attending ESL classes by the time of this study. Attention to diversity in backgrounds and in lengths of time in the ESL program and in Canada led to the selection of those three students from eight ESL students who had volunteered to participate. Table 2 summarizes the profiles of the students and their parents.

The two teachers were the sole ESL teachers in their respective schools. One was certified in ESL teaching and was quite experienced in working with ESL students; the other, although not formally specialized in the field, had taken on teaching ESL and was well experienced in working with ESL students by the time of this study. The two mainstream teachers each had over 10 years of teaching experience not only in their respective fields, but also with ESL students in mainstream classrooms.

\section{Data Collection and Analysis}

Data for this study were collected through semistructured interviews with the participants. Student and parent participants were interviewed individually in two sessions, each lasting 30 minutes. The ESL and mainstream teachers were each interviewed for one session lasting 45 minutes. Inter-

Table 2

Summary of Student-Parent Profiles

\begin{tabular}{|c|c|c|c|c|c|}
\hline Student & Age & Origin & $\begin{array}{l}\text { Years in } \\
\text { ESL class }\end{array}$ & Grade & Parent \\
\hline Camille (F) & 17 & S/America & $21 / 2$ & Senior high & $\begin{array}{l}\text { Nadia }(F) \\
\text { Full-time ESL student }\end{array}$ \\
\hline Juan (M) & 17 & Asia & $1+$ & Senior high & $\begin{array}{l}\text { Natalie }(F) \\
\text { Part time job }\end{array}$ \\
\hline Fiki (F) & 16 & Africa & $11 / 2$ & Junior high & $\begin{array}{l}\text { Edem (M) } \\
\text { Unemployed }\end{array}$ \\
\hline
\end{tabular}


views with all 10 participants were audiotaped and transcribed. Brief field notes written after each interview supplemented the interview data and were useful in following up on important leads with the participants.

Data were managed with QRS NUD*IST Vivo, a qualitative data analysis software package (Richards, 1999). Analysis followed an inductive thematic approach in order to discover overarching themes that emerged from data from individual participants and across participants (Miles \& Huberman, 1994). In analyzing the data, I was guided by three analytical steps: namely, unitizing textual data into idea units, coding categories, and integrating categories (Lincoln \& Guba, 1985). Three overarching themes that resulted from this process are discussed in detail: language barriers, ESL services, and support systems.

\section{Findings and Interpretation}

\section{Language Barriers}

The ESL students in this study faced challenges in their social and academic lives as a result of their limited knowledge of English. They all indicated that communication barriers existed between them and their English-speaking peers, resulting in a feeling of isolation. For example, the following views were expressed.

Trying getting into the conversation took me a while. I was just sitting there in the cafeteria listening to the other students talking. I didn't know what they were saying. It kind of makes you be like a lonely kid in school. But then if you know English, you can talk to them, so you don't feel as alone, like you are aside. (Camille)

I see my classmates; they speak English, so I was just quiet because I don't know anything. I was just quiet and listened to them. (Fiki)

It is difficult to make friends actually if you ... speak a different language; it's pretty hard because my English is not good enough to communicate. (Juan)

And Kathy, a mainstream teacher, reiterated this idea of students' isolation.

The ESL students tend to group together ... for several years they don't mix with the other students; even Canadian-born students of other cultures don't mix with the ESL students, the new immigrants. In my class, I have two girls from [countries A and B] and a boy from [country C] sitting together because they are the ones that don't know English and they are more comfortable with each other.

Because language mediates social interaction and higher mental processes (learning, Vygotsky, 1978; Wertsch, 1991), it can be argued that isolation 
due to language barriers put these students at a social and academic disadvantage. It is possible that their lack of interaction with their more knowledgeable peers made learning English and the culture that comes with it more difficult. We can speculate that this linguistic isolation would similarly limit their effective participation in the intellectual world of the classroom.

From the teacher's observation above, it seems that English language proficiency was an important determinant of group membership for these ESL students. Kathy gave her opinion on why the new immigrants did not mix with other students.

I think there's more of a social difference because, as I say, in the school we get all colors and shapes.... We have people, for example, East Indians that have been in Canada for generations and East Indians that have been here for two years. The same with blacks that have been in Canada for many years and blacks that are new immigrants. It seems like the older generations mix with whomever and the newer generation is sort of set apart for a while.

Language is important in establishing group membership (Gee, 1996; LippiGreen, 1997). From the above observations, it appears that these ESL students were isolated by their English-speaking peers because they lacked the language that, according to Gee, informs group members on how to behave in order to be recognized as such. I argue, therefore, that it was difficult for my research participants to negotiate group membership with their Englishspeaking peers. Yet group membership and interaction with speakers of their own languages was not possible either, because there were no members of their language communities in their schools. This aggravated the feeling of isolation for these students.

Moreover, it seems that language barriers determined the academic performance of these ESL students. Various participants reported instances of failure in the classroom. All parent participants acknowledged that their children were having difficulties performing well in the classroom as a result of limited English proficiency. Edem said about his daughter:

Fiki has a problem in learning subjects. She cannot write a letter to somebody, she cannot write a note to somebody in the office, she cannot write an application for job, she cannot fill a form. If you give this book to Fiki, she cannot read.

Nadia revealed that her daughter's grades in social studies and math dropped because of limited English language proficiency. Natalia acknowledged the same about her son: "Even if Juan does not tell me 'I don't understand this, mother,' but I know. The main thing I did was to buy him a dictionary." 
Among the students, Fiki's sentiment reflects the other students' experiences regarding their academic performance:

In my country I always passed all my courses because I know what they are saying ... because it is my language. But here it is different because it is not my language. I am just learning ... In my country all my report cards they are so good but here they are not good ... because here it is too hard. If you don't know English and you don't know how to read that good, it is too hard to get your report card to be that good.

Language difficulties had implications for these ESL students' career choices and their access to well-paid jobs after high school graduation. Because of their limited English proficiency, they took some nonacademic courses, which they felt demanded less English, in order to fulfill graduation requirements. Such courses lead only to immediate entry to the workforce, or to nonacademic postsecondary training and jobs. They are perceived to be relatively easy courses. Taking these courses in place of the academic courses required for university entrance creates a road-block to direct admission to university and well-paid professional jobs later in life. The participants observed:

With Communications 11 and 12, students can get their graduation certificate from high school but they don't have entry to college or university ... they will have to go back and do academic English to qualify for many programs in college, even technical programs. There's a lot of jobs you could do without academic courses but they are not well paid. (Kathy)

About his daughter's job prospects, Edem said:

There are some works you can do [involving] writing and some like McDonald. Fiki is taking Cafeteria classes. She can work in McDonald or in KFC ... but in another job, she cannot work because she don't know English.

Camille, who wants to pursue a career in astronomy, emphasized the need to perform well in all subjects, and especially in the academic English course: "I need English too, a lot; if you have no English, you are screwed, pretty much."

This academic requirement for direct university admission and access to well-paid jobs affects ESL students negatively. If their English proficiency has not improved significantly by the time they graduate from high school, they may shy away from upgrading their academic qualifications. As a result, their career choices will be limited and many high-paying professional careers requiring university degrees will be out of reach. 


\section{ESL Services}

English and ESL classes. Learning English as a second language was viewed as important in the process of the students' adjustment to the new environment. All students indicated that they had more than one ESL block each day in their first term in the new schools: Camille, Fiki, and Juan had two, three, and two blocks respectively. Each of these students appreciated being in their ESL classes.

I was glad I went to ESL because there they helped me out and they told me which one was the next class, where I was supposed to go, who was my teacher ... my teacher would just go and talk to my teachers and let them know I was an ESL student. (Camille)

If there was no ESL, I couldn't be in school because there is no class that was gonna teach me about English or something like that and there is no class that is gonna help me after the school or tomorrow morning because now when I am in ESL. If I went to my class and I have homework that I don't know how to do it, tomorrow I will come to [ESL teacher] and the teacher is gonna help me with the homework. In ESL class, they teach you English; they taught us English and how to learn everything in it. (Fiki)

Advantages [of being in the ESL class] are your language is getting good, they help me out, they help me with improving my English. (Juan)

In addition, the ESL class served as a safe place for the ESL students:

I feel more comfortable in my ESL class. (Juan)

When am in ESL class, I feel good but if I went to another class that is not ESL, I feel like am scared or something because if I want to say something to students I am gonna be afraid to say it. In the ESL [class] I can just say it like that. I am just thinking if I talk to students in the other class maybe they are not gonna understand me that good. (Fiki)

The teachers also understood the importance of the ESL class for these students:

They feel comfortable in this classroom; they know they can just come here and hang out if they don't have something that really, really needs doing ... the kids need a down time and this is where they can be themselves. In their other classrooms they are always nervous and always on edge because they are thinking ... "I don't know what is going on." (Cindy)

[The ESL class] gives them a half of the day where they don't have to feel like they have to fit it ... they feel safe not to know something. They 
don't feel like they are going to be ridiculed or pointed out that they don't know the meaning of a certain word because that is the job of that teacher. (Wayne)

Being in an ESL class helped these students learn other school subjects through help both with homework and with understanding test questions. Students and parents indicated that the ESL teachers were helpful in facilitating the understanding of course content. The ESL teachers also indicated their commitment to helping the students to perform well in their other classes. Wayne, one of the mainstream teachers, said:

The class is also a good opportunity for them to sit back and reinforce some of the things they have learned. If they hear something that I say in the classroom, a certain phrase or a certain instruction and they don't quite understand it even if I explain it in different ways, they can go to the ESL classroom and that teacher may give them another way of understanding things. That teacher has the time and the resources to sit down and not worry about 30 other kids in the classroom and can get to focus a little more on getting to the help they needed.

Jason, one of the ESL teachers, commented, "ESL class provides a chance to go over the concepts of the day's work ... and assist in test review." Roessingh (1995) proposes that in order to help ESL students succeed in high school mainstream classrooms, ESL teachers must become more conversant with the demands and content requirements of the mainstream curriculum. I found it impressive that ESL teachers in this study seemed to have risen to this challenge.

The nature of the ESL program. The withdrawal ESL program model (see Table 1) was provided in the schools where this study was conducted. However, instead of withdrawing students for ESL instruction based on their English-language proficiency (e.g., beginners, intermediate, and advanced) or grade levels, students from various grades and with varying English proficiency levels converged in the ESL class/resource room during their designated ESL class blocks. Cindy commented on the program's setup: "In my class I have students that have just arrived into the country and ... students who have been here for a while. My class basically is run like a learning assistance." In addition to immigrant students with varying language proficiency levels, Canadian-born students (mainly of First Nations origin) who spoke an English dialect other than the one used in schools were also placed in the ESL class to learn English as a second dialect (ESD). Jason described the nature of his ESL class.

My classes are a real mix ... I will have a block that is ESL/ESD, so I will have some students who are working with ESL materials and some are 
ESD ... and I also might have within that same block other students who are working on optional materials.

Two teachers expressed unease with heterogeneous ESL classes.

If you mix all different kids in different classes and call it ESL but you are still working with many other kinds of kids, that's not ESL, I don't think it is. (Jason)

When all levels are mixed together as what [teacher X] has here, it often becomes just a support for the other courses rather than actually working through specific English skills. (Kathy)

Camille, an ESL student, found that having ESL students with varying English proficiency levels in one ESL class had both pros and cons.

I think that is good, sometimes bad. Good thing is because it helps like if you know English a little bit then you will help someone who does not know anything, then you are even learning how to teach somebody else something what you are just learning ... so you have to find a way to make them understand.... The bad thing is maybe the advanced people don't keep learning.

Although participants expressed dissatisfaction with the nature of the ESL program in their schools, they inevitably accepted it. On whether she was satisfied with the nature of the program, Cindy said,

Well, I can't really see that it could be any other way, not up here. We don't have the huge numbers like they have in Vancouver. In

Vancouver they have the ESL classes level 1, 2, and 3 ... here we can't do that because of the lack of numbers.

Jason also saw the impossibility of grouping ESL students into varying levels, "I think that in [my school] we don't have as many ESL students ... numbers are not there to warrant having separate ESL classes."

These participants' observations confirmed my initial assumption that there was a relationship between numbers of ESL students and the nature of ESL programming in the schools involved in this study. Furthermore, the type of ESL programming in these schools affects teaching and students' learning.

Problems facing ESL programming. It seems that mixing ESL and other student groups (e.g., ESD) in an ESL classroom resulted in high student numbers per teacher. The mix and the high student-teacher ratio made effective work challenging for ESL teachers and students alike. According to Jason,

It is difficult to have mixed groups like that to actually have a small group session with three or four students where you are getting them to 
interact and communicate more ... it's hard to do one-on-one things like if you got 12 or 14 students all doing different things ... it's hard to kind of spread yourself around.

Cindy explained that trying to help everybody in the room was difficult because "you are helping like every five minutes ... you are trying to help as many students as you can ... there's always different assignments going on. You just have to be very flexible, incredibly flexible." Camille related a similar experience through her comment that getting the teacher's help whenever an ESL student needed it was not always possible because of the teacher-student ratio, as well as because of the students' differing English language levels, which resulted in some students needing more time with teachers than others. In her words,

Right now we have two teachers in our class for like about 20 ... but then sometimes you try to get help but then they have to take their time explaining things [to other students] so there is not enough time, so that is when you have to like work by yourself.

Kathy also observed that the way the ESL program was structured did not provide adequate opportunities for students to learn English skills:

[Teacher $\mathrm{X}$ ] is trying to do everything at every level with too many students; so, for them to be able to do structured lessons that gradually build the skills is really difficult. It would be useful if they were able to have a class where their job was to learn English structure and grammar and vocabulary. But I don't see this is possible here the way they organize it [the ESL program] because there's so many levels and so little time for the ESL.

Teacher participants attributed the problems preventing adequate ESL support to inadequate funding for ESL services in their schools. Cindy, whose ESL teaching time had been reduced, pointed out that the few ESL blocks offered contributed to a high student-teacher ratio in her classroom. She perceived that increased funding would have the potential to enable her to offer adequate ESL support to all students.

The problem is about funding at the school. We used to have two and a half teachers working and now it's just me, half-time. With the budget cuts, the teachers are expected to do more and more. The ratio used to be one full-time teacher for every 38 ESL students and now it's one to 76. If you don't have 76 students, you are not full time. With a little more funding, it would be possible to have an ESL teacher all day. If we could offer ESL for four blocks, then I would be able to help all students and I would have fewer students in each block. 
Jason, the other ESL teacher, expressed the need for more funding in order to improve not only the time for ESL support, but also the organization of the program in his school.

I would like to see the government put funding back where it was. This semester I have one block and that is not devoted to ESL students only. It's mixed up with a bunch of other stuff. I have ESD kids and others who are taking pre-employment courses. I would certainly like to have more time to work with ESL students and not have them thrown in with lots of other kids.

Similarly, Kathy commented,

Improving ESL support would take an administration that understands the needs of ESL students better and didn't just assume that they are gonna learn English naturally with one very overworked and helpful teacher. The students need more tutoring when they first arrive, where you may only have three or four or five students working with one teacher rather than 16; and that they would be grouped by level to some degree so that you can have some skills for each level that they can work on. This is not possible without funding to hire more ESL teachers or aides.

Positive program aspects. Despite the problems encountered by ESL teachers and students due to few ESL students and insufficient ESL services, three positive aspects of the program were evident from the ESL teachers' comments. First, because the program was not organized in levels, there was no specified time when ESL students were withdrawn from the ESL class. Although the end of a five-year funding limit would typically disqualify a student from receiving further ESL support, the generally low numbers of ESL students made it possible for ESL teachers in these schools to volunteer their time to provide ESL support to students who still needed it, either in the ESL class or informally. Cindy commented:

Last semester I was only working half-time ... but I had a bunch of students who needed help. I just tell them [to] tell me a day or two [ahead], so I don't make other appointments or whatever, and if I can stay [to help] I stay. So, some kids came almost two or three times in a week to do their stuff with me.

Jason also continued to support ESL students who needed help even though they were no longer getting funding:

There is a maximum of five years of funding in this province; so, beyond that five years they don't get the ESL funding but I have some students who are not getting any ESL time this semester, and they can always come and talk to me after school or whenever. 
Second, the low numbers of ESL students in the schools enabled the ESL teachers to know individual students and their needs, which resulted in teachers taking extra responsibility for students' progress and success. As well, these teachers followed the progress of students who voluntarily opted out of ESL class and therefore were not allocated ESL time in their timetables. The teachers inquired about the students' progress whenever they met them in the hallways and also talked to their mainstream classroom teachers. According to Cindy, "Some students decide that they don't need ESL help anymore ... you talk to them in the hallways ... because what happens I become like a mother to them ... I kind of keep them on track."

Third, more collaboration between ESL and subject-area teachers was possible because the ESL students were few, making it possible for the subject-area teachers to monitor their progress too.

Educational planners of education might consider capitalizing on such determination by ESL teachers to meet the needs of their ESL students, albeit in challenging situations: administrators should consider providing sufficient resources to enable ESL teachers to meet the ongoing needs of students as part of their professional assignment rather than through unfunded voluntary services.

\section{Support Systems}

Apart from the support from ESL teachers reported by student participants, families themselves featured prominently as providers of moral and practical support in learning English and other school subjects. The parents, for example, reported that they encouraged the students to practice speaking English and reading English materials and also helped with homework if they could. Edem, for example, indicated that he had some knowledge of English grammar and writing, which he used to help his daughter improve her English. Edem said,

I open a book and give Fiki a test or homework. I give her dictation of some words, today 20 , tomorrow $50 \ldots$ up to 100,150 words. Sometimes if I don't have work I can call her, bring your books, open this, what is this? If she didn't know, I will explain.... In the morning there is a newspaper. I can tell her, can you read this passage for me?

Another parent, Natalia, said,

First of all I give Juan motherly advice and moral support; I told him if you don't really understand the way your teacher is talking English, don't feel shy to ask ... or if you have classmates, you can ask him or her about the subjects that you don't understand.

Natalia also encouraged her son to read English print materials in order to improve his English: "I always remind him to read more, read more books in 
English, read magazines ... I also buy him a Canadian English dictionary ... it helps and like, he doesn't understand a word, he checks it."

Still, support from school administrators and other staff such as mainstream teachers, counselors, and coaches was conspicuously lacking in participant reports. Such support is, however, critical not only in providing sufficient ESL services, but also in guiding and counseling ESL students on making and pursuing decisions that can lead to academic success.

\section{Conclusion, Implications, and Recommendations \\ Conclusion}

Immigrant students who attend high schools in small Canadian cities are likely to be few in the schools, and as a result they may receive limited ESL services and support from school personnel. This article identifies some problems and opportunities arising from having low numbers of ESL students in schools. ESL teachers in this study have created additional opportunities to meet the needs of ESL students by sometimes providing voluntary services. However, these teachers need the support of education planners, parents, school administrators, and other school staff so as to make school resources and curriculum content fully accessible to ESL students. The great determination demonstrated by parents in assisting their children to learn English and to succeed in school gives reason for hope that there could be a basis for effective collaborative efforts among all parties-school administrators, teachers, and the community-to better meet the needs of ESL students.

Yet it is apparent from this study that ESL students' low English-language proficiency has implications for their interaction, academic success, and future careers. Ensuring students' success and positive experiences with regard to these implications requires improved ESL support and purposeful structures to facilitate social interaction. Improved support requires adequate and stable funding to increase ESL support time, hire teachers' aides, and reduce the number of students per teacher. Supportive school administrators and collaboration among ESL and mainstream teachers, parents, and society at large can foster acceptance of diversity, thereby enhancing support for ESL students. In particular, educators could use the following strategies to initiate and support interaction for ESL students.

\section{Buddy System}

Buddies would provide a good starting point for orienting ESL students to the schools' language and operations. A buddy could be a source of psychological and social comfort for the new student. Some schools provide buddies to new ESL students for a few days or the first week of school. However, because the adjustment process of ESL students is ongoing and may take some students a long time, participants' responses imply that buddies would 
be beneficial for ESL students for longer periods. Such buddyship may develop into long-lasting friendships through which ESL students may have opportunities to practice English.

\section{Peer Tutoring/Counseling}

Peer tutoring and counseling support systems are important in encouraging not only student friendships and interaction, but also cooperative learning (Coelho, 1994b). Peer tutors, especially at the high-school level, can benefit teachers by providing extra help to ESL students. The peer tutoring strategy also supports the sociocultural dimension of learning as a process of interaction with more knowledgeable adults or peers. The advantages of this strategy are fourfold: (a) it recognizes the tutors' abilities, (b) it reinforces tutors' understanding of the material they are tutoring, (c) it provides extra academic support for students who need it, and (d) the whole school is reconstructed as a community of learners (Coelho).

\section{Participation in Extracurricular Activities}

Extracurricular activities and clubs have been identified as providing suitable opportunities for ESL students' interaction with their mainstream peers (Harklau, 1994; Watt et al., 1996). However, constraints such as language, coursework demands, or lack of relevance to the students' own culture may discourage immigrant students from participating in these activities (Harklau). Because these constraints have implications not only for ESL students' social interaction, but also for their English-language development and their sense of belonging, schools might provide mentors to ESL students who could, for example, demonstrate that it is possible to perform well in both academic and out-of-class activities. It is also important for educators to be sensitive to differences in conditions (e.g., climate) that may favor certain activities and not others. Snow sports that are available in Canada clearly will not, for example, be familiar to most students from tropical countries. Teachers and mainstream students could encourage ESL students to participate by being patient with them as they try to learn new sports and games that were not available in their home countries.

\section{Positive Classroom and School Atmosphere}

A comfortable classroom and school atmosphere that values, encourages, and celebrates diversity and efforts at language use can encourage ESL students to interact in the classroom and thus enhance their understanding of curriculum content. Teachers can promote a welcoming environment by correcting ESL students' utterances in a nonthreatening way, such as through revoicing (Gibbons, 2003; O'Connor \& Michaels, 1996), recognizing their presence in the classroom, and making course content more comprehensible through strategies such as reducing the speed and complexity of speech, providing task instructions in writing as well as orally, repeating key 
points several times, pausing, and frequently checking for comprehension. Other useful strategies include the use of visuals such as maps, pictures, and graphs, which serve to contextualize abstract concepts and make information more accessible to ESL students (Cummins, 1994; Harklau, 1994). Use of curriculum topics from a wide range of cultural traditions not only validates diversity but also presents ESL students with familiar topics that they may feel more comfortable discussing (Toohey, 2000): inviting ESL students to contribute their ideas on issues with which they are familiar can provide good opportunities to build their confidence in classroom participation.

\section{Suggestions for Further Research}

There is a need for future research adopting a longitudinal approach, in which participants would not only be interviewed at various stages, but also observed in varied schools settings such as the classroom, the cafeteria, the gym, and the sports field. Such information would increase understanding of issues that affect ESL students such as their adjustment, integration, and learning strategies. In addition, tracking and investigating former ESL students from high schools with low ESL enrollments could be important in depicting trends in the provision of ESL support over the years in the context of the effect on ESL students' postsecondary and career lives. Findings from such studies would be informative for policymakers, education planners, school administrators, teachers, and other school staff with respect to the possible need for new directions in the provision of support for high school ESL students in settings where their numbers are relatively low. Finally, research exploring ESL policy and including the perspectives of education planners and school administrators may be useful in formulating policies that most effectively address ESL services and support for ESL students.

\section{The Author}

Lucy Karanja is a doctoral candidate in the Faculty of Education at the University of Western Ontario. Her research interests include language use in classrooms, ESL education, multimodal literacy, and comparative and international education.

\section{References}

Adair-Hauck, B., \& Donato, R. (1994). Foreign language explanations within the Zone of Proximal Development. Canadian Modern Language Review, 50, 532-557.

Ashworth, M. (2000). Effective teachers, effective schools: Second-language teaching in Australia, Canada, England and the United States. Toronto, ON: Pippin.

Baker, C. (1996). Foundations of bilingual education and bilingualism (2nd ed.). Clevedon, UK: Multilingual Matters.

Brinton, D., Sasser, L., \& Winningham, B. (1991). Language minority students in multicultural classrooms. In P. Richard-Amato \& M. Snow (Eds.), The multicultural classroom: Reading for content-area teachers (pp. 5-15). White Plains, NY: Longman.

British Columbia Ministry of Education. (2002). Policy document: K-12 funding-English as a second language (ESL). Retrieved November 15, 2004, from: http://www.bced.gov.bc.ca/policy/policies/funding_esl.htm 
Coelho, E. (1994a). Social integration of immigrant and refugee children. In F. Genesee (Ed.), Educating second language children: The whole child, the whole curriculum, the whole community (pp. 301-327). New York: Cambridge University Press.

Coelho, E. (1994b). Learning together in the multicultural classroom. Markham, ON: Pippin.

Coelho, E. (1998). Teaching and learning in multicultural schools. Toronto, ON: Multilingual Matters.

Collier, V. (1987). Age and rate of acquisition of second language for academic purposes. TESOL Quarterly, 21, 617-641.

Cummins, J. (1981). Age on arrival and immigrant second language learning in Canada: A reassessment. Applied Linguistics, 2(2), 132-149.

Cummins, J. (1994). The acquisition of English as a second language. In K. SpangenbergUrbschat \& R. Pritchard (Eds.), Kids come in all languages: Reading instruction for ESL students (pp. 36-62). Newark, DE: International Reading Association.

Derwing, T., DeCorby, E., Ichikawa, J., \& Jamieson, K. (1999). Some factors that affect the success of ESL high school students. Canadian Modern Language Review, 55, 532-547.

Gee, J. (1996). Social linguistics and literacies: Ideologies in discourses (2nd ed.). London: Taylor \& Francis.

Gibbons, P. (2003). Mediating language learning: Teacher interactions with ESL students in a content-based classroom. TESOL Quarterly, 37, 247-273.

Gunderson, L. (2000). Voices of the teenage diasporas. Journal of Adolescent and Adult Literacy, 43, 692-706.

Harklau, L. (1994). ESL versus mainstream classes: Contrasting L2 learning environments. TESOL Quarterly, 28, 241-272.

Hébert, T. \& Reis, S. (1999). Culturally diverse high-achieving students in an urban high school. Urban Education, 34, 428-457.

Leung, C. (2001). English as an additional language: Distinct language focus or diffused curriculum concerns? Language and Education, 15(1), 33-55.

Lincoln, Y., \& Guba, E. (1984). Naturalistic inquiry. Newbury Park, CA: Sage.

Lippi-Green, R. (1997). English with an accent: Language, ideology, and discrimination in the United States. London, UK: Routledge.

Merriam, S. (1988). Case study research in education: A qualitative approach. San Francisco, CA: Jossey-Bass.

Miles, M., \& Huberman, A. (1994). Qualitative data analysis: An expanded sourcebook (2nd ed.). Thousand Oaks, CA: Sage.

Miller, J. (1997). Reframing methodology in second language research: From language to discourse. Australian Educational Researcher, 24(3), 43-56.

O'Connor, M., \& Michaels, S. (1996). Shifting participant frameworks: Orchestrating thinking practices in group discussion. In D. Hicks (Ed.), Discourse, learning, and schooling (pp. 63-103). Oakleigh, Melbourne: Cambridge University Press.

Parkin, F., \& Sidnell, F. (1992). ESL is everybody's business. Markham, ON: Pembroke.

Ponsford, K., \& Lapadat, J. (2001). Academically capable students who are failing in high school: Perceptions about achievement. Canadian Journal of Counselling, 35, 137-156.

Richards, L. (1999). Using NVivo in qualitative research. Thousand Oaks, CA: Sage.

Roessingh, H. (1995). Teaching to diversity: Meaningful inclusion of ESL students in high school mainstream settings. Exceptionality Education Canada, 5(1), 65-81.

Spangenberg-Urbschat, K., \& Pritchard, R. (1994). Meeting the challenge of diversity. In K. Spangenberg-Urbschat \& R. Pritchard (Eds.), Kids come in all languages: Reading instruction for ESL students (pp. 1- 5). Newark, DE: International Reading Association.

Toohey, K. (2000). Learning English at school: Identity, social relations and classroom practice. Toronto, ON: Multilingual Matters.

Toohey, K., \& Norton, B. (2001). Changing perspectives on good learners. TESOL Quarterly, 35, 307-322. 
Vygotsky, L. (1978). Mind in society: The development of higher psychological processes. Cambridge, MA: Harvard University Press.

Watt, D., \& Roessingh, H. (1994). ESL dropout: The myth of educational equity. Alberta Journal of Educational Research, 40, 283-296.

Watt, D., \& Roessingh, H. (2001). The dynamics of ESL drop-out: Plus ça change ... Canadian Modern Language Review, 58, 204- 224.

Watt, D., Roessingh, H., \& Bosetti, L. (1996). Success and failure stories of ESL students' educational and cultural adjustment to high school. Urban Education, 31(2), 199-221.

Wertsch, J. (1991). Voices of the mind: A sociocultural approach to mediated action. Cambridge, MA: Harvard University Press.

Yin, R. (2003). Case study research: Design and methods (3rd ed.). Thousand Oaks, CA: Sage. 